\title{
IDENTIFIKASI PERMASALAHAN PRODUKSI GARAM LOKAL DI KABUPATEN FLORES TIMUR
}

\author{
Yosephina Margaretha Jawa Batafor \\ Program Studi Teknologi Hasil Perikanan Fakultas Teknologi \\ Institut Keguruan dan Teknologi Larantuka, Larantuka, Flores Timur \\ E-mail: yosephinabatafor@yahoo.com
}

\begin{abstract}
ABSTRAK
Flores Timur berpotensi memiliki bahan dasar pembuatan garam dan termasuk dalam sentra produksi garam Indonesia. Secara fisik, 6 lokasi sampel garam lokal di Kabupaten Flores Timur belum memenuhi syarat mutu garam konsumsi beryodium. Tujuan penelitian mendata sentra produksi garam, mengkaji permasalahan produksi dan pemasaran garam lokal, dan mengetahui kadar $\mathrm{NaCl}$. Metode untuk mendata sentra produksi garam yaitu mengambil contoh garam yang dihasilkan oleh petani garam di Flores Daratan dan di pulau Adonara. Garam yang dijadikan contoh adalah garam yang dihasilkan oleh petani tradisional/lokal menggunakan tanah sebagai meja kristalisasinya. Kandungan $\mathrm{NaCl}$ dianalisa di laboratorium Kimia Universitas Nusa Cendana dengan cara Kohman. Data dianalisa dengan metode deskriptif. Garam masih dikemas menggunakan wadah kemas tradisional. Kadar $\mathrm{NaCl}$ dari 6 lokasi sampel garam belum memenuhi SNI 3556:2010 dan perlu ditingkatkan kualitas garam dengan melakukan pengujian fisik dan kimia.
\end{abstract}

Kata kunci: Flores Timur; Garam; Kadar NaCl.

\section{PROBLEM IDENTIFICATION ON LOCAL SALT PRODUCTION IN EAST FLORES REGENCY}

\begin{abstract}
East Flores has high potency to have basic ingredients for salt production and it is included in the Indonesian salt production center. Physically, 6 local salt sample locations in East Flores Regency do not meet the quality requirements for iodized consumption salt. The purpose of the study is to record the centra salt production, examine the problems of local salt production and marketing, and determine levels of $\mathrm{NaCl}$. The method for recording salt production centers is to take samples of salt produced by salt farmers in mainland Flores and on the island of Adonara. The salt used as the sample is salt produced by traditional/local farmers using the soil as a crystallization table. The content of $\mathrm{NaCl}$ was analyzed in the Chemistry laboratory of the University of Nusa Cendana by using of Kohman Method. Data were analyzed using descriptive methods. Salt is still packaged using traditional packaging containers. NaCl levels from 6 locations of salt samples do not met SNI 3556: 2010, it is necessary to improve the quality of salt by conducting physical and chemical testing.
\end{abstract}

Key words: East Flores; Salt; $\mathrm{NaCl}$ levels.

\section{PENDAHULUAN}

Flores Timur merupakan wilayah kepulauan dengan luas $3079,23 \mathrm{~km}^{2}$, berbatasan dengan Kabupaten Alor di timur, Kabupaten Sikka di barat, utara dengan laut Flores, dan selatan dengan laut Sawu. Kabupaten yang terletak di ujung Timur Pulau Flores ini terkenal sebagai Kabupaten Kepulauan, terdiri dari 3 buah pulau yaitu Adonara, Solor, dan Flores Daratan, serta diapit oleh beberapa buah pulau kecil lainnya seperti pulau Konga, pulau Waibalun, dan Pulau Mas. Dinas Perikanan dan Kelautan Kabupaten Flores Timur (2007) mencatat luas wilayah laut Flores Timur kurang lebih $3.818,32$ atau $67,92 \%$ dari luas wilayah Kabupaten Flores Timur keseluruhan. Flores Timur memiliki potensi air laut yang baik sebagai bahan dasar pembuatan garam (natrium klorida) dan termasuk dalam sentra produksi garam (Gambar 1).

Tingginya permintaan garam domestik tidak bisa diimbangi oleh produksi garam lokal, bahkan total produksi garam yang dihasilkan oleh petani tambak (garam rakyat) dan PT. Garam berfluktuasi setiap tahunnya. Jumlah produksi garam domestik tahun 2012 mengalami peningkatan dibandingkan 2011, namun turun di tahun 2013 dan naik kembali di tahun 2014 (KKP, 2015a). Data Kementerian Kelautan dan Perikanan (KKP, 2015), produksi garam nasional pada tahun 2015 mencapai 2,84 juta ton. Sebanyak 2,5 juta ton diproduksi oleh garam rakyat yang digunakan untuk memenuhi kebutuhan garam konsumsi, dan sisanya berupa garam industri yang diproduksi PT. Garam. Jumlah kebutuhan garam dengan kualitas tinggi mencapai $61,5 \%$, sekitar $31 \%$ yang bisa dipenuhi oleh kebutuhan garam yang dihasilkan di dalam negeri. Data KKP (2015), menunjukkan bahwa kualitas garam lokal yang dihasilkan khususnya oleh petambak garam (garam rakyat) tidak seragam sehingga penjualan garam petani tambak juga digolongkan kedalam beberapa kelas sesuai dengan kualitasnya. Kualitas pertama $\left(\mathrm{KW}_{1}\right)$ adalah garam dengan tingkat $\mathrm{NaCl}$ antara 95$98 \%$, kualitas kedua $\left(\mathrm{KW}_{2}\right)$ mengandung $\mathrm{NaCl}$ antara 90-95\%, dan kualitas ketiga $\left(\mathrm{KW}_{3}\right)$ berkadar $\mathrm{NaCl}$ kurang dari $90 \%$.

Rositawati et al. (2013) melaporkan, garam diperoleh dengan tiga cara yaitu penguapan air laut dengan sinar matahari, penambangan batuan garam (rock salt) dan sumur air garam (brine). Menurut Sulistyaningsih et al. (2010), garam adalah suatu kumpulan senyawa kimia dengan penyusun terbesar 
adalah natrium klorida $(\mathrm{NaCl})$ dan pengotor yaitu kalsium sulfat $\left(\mathrm{CaSO}_{4}\right)$, magnesium sulfat $\left(\mathrm{MgSO}_{4}\right)$, dan magnesium klorida $\left(\mathrm{MgCl}_{2}\right)$.

Garam tergantung pada kandungan NaClnya, kandungan $\mathrm{NaCl}$ tergantung pada lokasi dimana air laut yang diambil, dan jenis dasar tambak/meja garam akan mempengaruhi kualitas garam yang dihasilkan. Meja garam adalah lahan yang digunakan untuk pembuatan garam atau yang sering disebut tempat pengkristalan. Meja garam yang dipakai oleh petani garam sejak dahulu adalah meja garam tanah (Oktavian, 2013). Indonesia masih harus mengimpor garam dari negara lain, sementara kebutuhan garam nasional dari tahun ke tahun semakin meningkat seiring dengan pertambahan penduduk dan perkembangan industri di Indonesia. Kualitas garam yang dikelola secara tradisional, menghasilkan garam yang belum memenuhi syarat, hingga saat ini belum ada pengujian mengenai kualitas garam dan pada umumnya harus diolah kembali untuk dijadikan garam konsumsi maupun garam industri. Salah satu budaya masyarakat setempat adalah memproduksi garam lokal untuk dimanfaatkan sebagai konsumsi sendiri maupun untuk di jual.

Indikator yang dipersyaratkan oleh pembeli adalah kandungan $\mathrm{NaCl}$ yang menjadi syarat dalam pemasaran. Petani garam tidak pernah mendapatkan kepastian tentang kandungan $\mathrm{NaCl}$ dari garam yang dihasilkannya. Pembeli tidak pernah menguji kandungan $\mathrm{NaCl}$ dari garam yang dibeli dari petani garam sehingga petani garam selalu dirugikan hanya karena penetapan sepihak dari pembeli.
Tujuan penelitian ini untuk mendata sentra produksi garam, mengetahui permasalahan produksi garam lokal, dan melakukan pengujian kadar $\mathrm{NaCl}$. Hasil penelitian diharapkan bermanfaat untuk meningkatkan kualiatas garam lokal di Kabupaten Flores Timur, khususnya peneliti bisa menginformasikan kandungan dalam garam lokal yang dipasarkan pada pasar tradisional di Kabupaten Flores Timur. Penelitian ini juga merupakan indikator capaian yang terukur dan merujuk pada syarat mutu garam konsumsi beriodium (SNI 3556:2010).

\section{METODE}

Penelitian dilaksanakan pada bulan Juli sampai September 2019, di 6 lokasi pengambilan sampel di wilayah Flores Timur dengan menggunakan wadah penampung garam. Secara umum, sebaran sentra produksi garam di Indonesia ditunjukkan pada Gambar 1. Metode yang digunakan untuk pengambilan sampel adalah metode survei. Sampel yang digunakan yaitu garam yang dihasilkan oleh petani garam di Flores Daratan dan di pulau Adonara. Garam yang dijadikan contoh adalah garam yang dihasilkan oleh petani tradisional/lokal menggunakan tanah sebagai meja kristalisasinya. Data dianalisa dengan metode deskriptif, yaitu dengan menyajikan data dalam bentuk gambar dan tabel. Penentuan lokasi pengambilan sampel berdasarkan hasil survei pemasaran garam lokal di pasar tradisional Kabupaten Flores Timur.

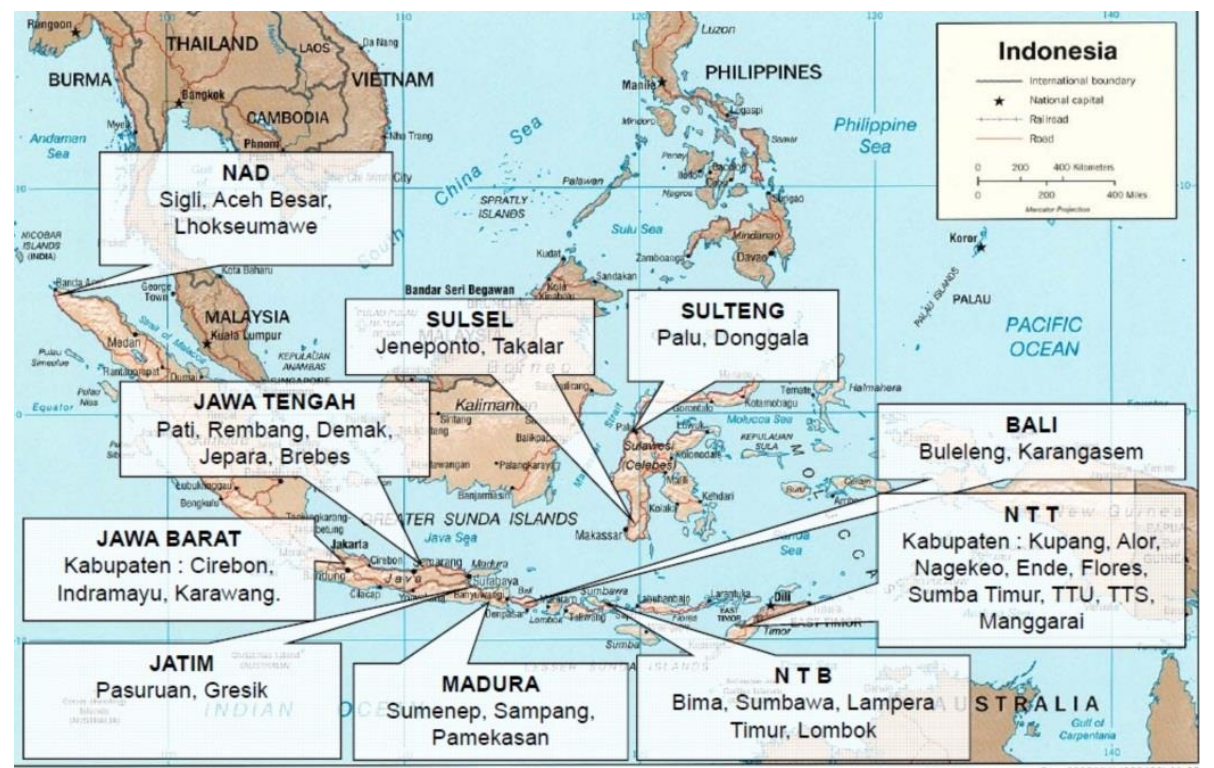

Gambar 1 Sentra produksi garam.

(Suamber : Kementerian Perindustrian, 2016)

Lokasi pengambilan sampel di Flores Daratan diberi kode KL, LL, KD, AP, L, dan di pulau Adonara diberi kode M (Tabel 1). Semua sampel dianalisa di laboratorium Kimia Universitas Nusa Cendana untuk kandungan $\mathrm{NaCl}$ dengan cara Kohman. Prinsip metode Kohman yaitu mengekstraksi sampel sehingga garam $\mathrm{NaCl}$ dipisah dengan lemak kemudian dititrasi (Sudarmadji et al., 1997). Sampel yang telah dihaluskan ditimbang sebanyak $5 \mathrm{~g}$, diekstrak menggunakan aquades panas $10-20 \mathrm{ml}$, ditunggu beberapa lama sehingga semua garam $(\mathrm{NaCl})$ larut dan terpisah dengan lemak, ekstraksi diulang beberapa kali (8-10). Cairan hasil ekstraksi ditampung dalam wadah kemudian ditambah $3 \mathrm{ml}$ kalium khromat 
5\% dan dititrasi dengan $\mathrm{Ag} \mathrm{NO}_{3}$ 0,1 $\mathrm{N}$ secara perlahanlahan sampai warna menjadi merah bata (Rinto et al., 2009).

Tabel 1 Lokasi pengambilan sampel penelitian

\begin{tabular}{cl}
\hline Kode Sampel & Lokasi \\
\hline KL & Desa Sinar Hading \\
LL & Desa Lewolaga \\
KD & Desa Kolaka (Dusun \\
& Kolidatang) \\
AP & Desa Mokantarak \\
L & Desa Kolaka (Dusun Laka) \\
M & Desa Pledo (Dusun Mekko) \\
\hline
\end{tabular}

\section{HASIL DAN PEMBAHASAN}

\section{Sentra Produksi Garam Lokal}

Produksi garam dilakukan secara individual oleh petani garam sehingga produksi garam mempunyai produktivitas yang rendah dan kualitas garam yang relatif rendah pula sehingga tidak memenuhi spesifikasi yang disyaratkan oleh industri di dalam negeri (Efendy et al., 2016). Apabila dibandingkan antara kebutuhan nasional dan kemampuan produksi, maka produksi garam nasional hanya mampu memenuhi kebutuhan dari sisi konsumsi saja, sementara untuk kebutuhan bahan baku industri masih bergantung pada impor. Garam untuk konsumsi telah dipenuhi oleh produksi dalam negeri, ternyata sebagian besar produksi garam rakyat tersebut masih membutuhkan proses pengolahan lebih lanjut untuk dapat memenuhi standar yang dibutuhkan hingga layak dikonsumsi oleh masyarakat (Efendy etal., 2014).

Perairan Flores Timur memiliki kondisi kualitas perairan yang cukup baik. Hal ini terlihat dari survei yang dilakukan di beberapa stasiun pengamatan yang mencakup seluruh perairan di Kabupaten Flores Timur (Setiawan, 2013). Kondisi kualitas perairan yang cukup baik, bisa menghasilkan produksi non tangkap seperti garam lokal yang diproduksi oleh petani garam yang ada di Kabupaten Flores Timur. Garam lokal yang dihasilkan di Kabupaten Flores Timur disajikan dalam Gambar 2.

Kode dan keterangan sampel dapat dilihat pada Gambar 2 diatas. Kode 1 - 5 adalah gambar garam yang diambil di Flores Daratan, sedangkan kode 6 adalah gambar garam yang diambil di pulau Adonara. Secara umum proses pembuatan garam untuk 6 lokasi menggunakan penguapan air laut meliputi: persiapan lahan dengan cara menggembur dan menjemur tanah sampai kering; tanah yang sudah kering di pindahkan kedalam wadah parapara; tanah di siram dengan air laut; air hasil tirisan (air tua) di tampung pada ember; air tua dimasak pada wadah yang sudah disiapkan dengan suhu $84,8^{\circ} \mathrm{C}$; setelah berapa jam kemudian terjadilah kristal garam; dan pengeringan garam. Faktor cuaca yang dikombinasikan dengan teknik pengolahan yang relatif sederhana/tradisional mengakibatkan produktivitas garam di Indonesia tergolong rendah.

Sistem teknologi yang digunakan dalam pembuatan garam di Indonesia mayoritas masih mengandalkan penguapan air laut menggunakan sinar matahari pada areal tambak/di atas tanah (Aditya P \& Alhayat, 2016). Garam dikemas menggunakan wadah kemas tradisional berbahan dasar anyaman daun lontar dan dipasarkan dipasar tradisional (Gambar 3). Ampas hasil penyaringan garam berupa garam batu yang akan dijadikan pakan ternak. Pembuatan garam melalui penguapan air laut dengan menggunakan sumber panas matahari, sangat tergantung pada kondisi iklim dan cuaca suatu daerah (Rusiyanto et al., 2013). Kualitas garam yang dikelola secara tradisional pada umumnya harus diolah kembali untuk dijadikan garam konsumsi maupun untuk garam industri (Rositawati et al., 2013).
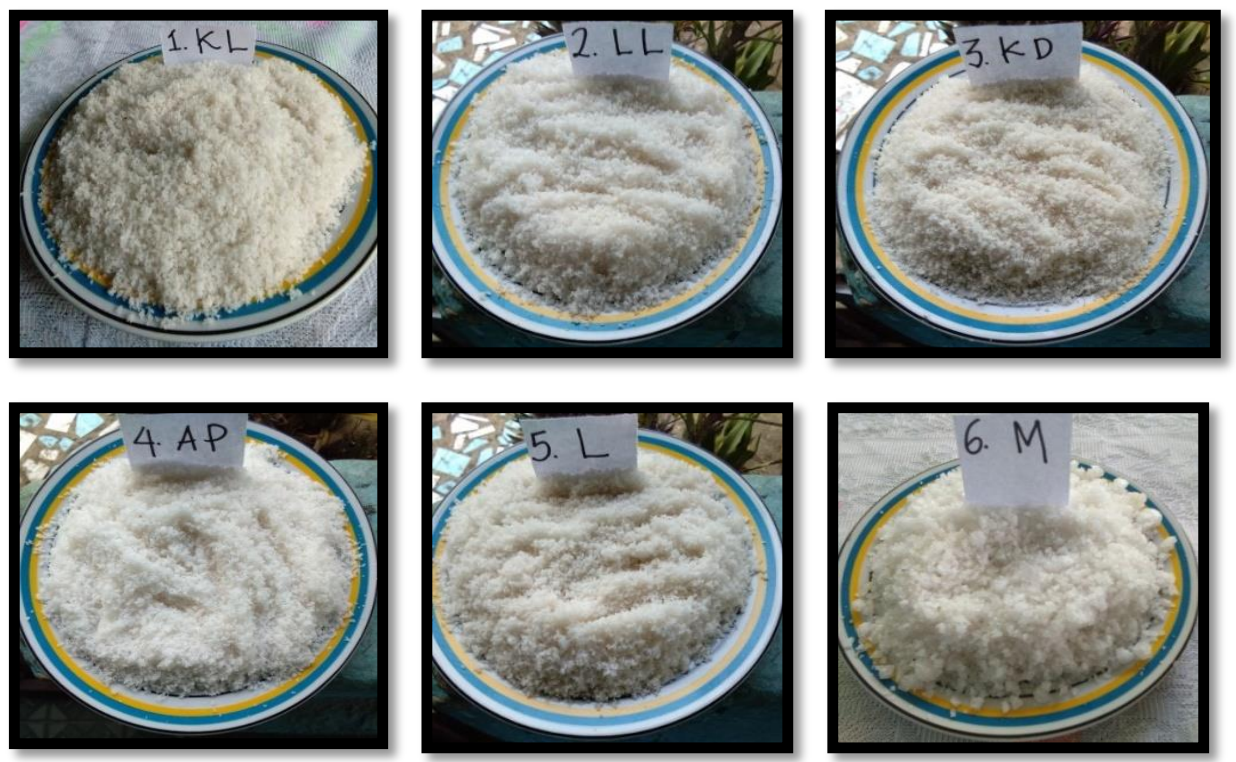

Gambar 2 Garam lokal yang dihasilkan di Kabupaten Flores Timur. 


\section{Pemasaran Garam Lokal}

Informasi yang disajikan dari Gambar 3 sebagai berikut: garam dikemas menggunakan wadah kemas tradisional berbahan dasar anyaman daun lontar dan dipasarkan dipasar tradisional di Kabupaten Flores Timur; setiap kemasan dijual dengan harga Rp 10.000,00. Petani garam dalam hal ini adalah ibu-ibu yang melakukan proses pemasakan garam dan yang terjun langsung ke pasar tradisional untuk melakukan proses jual beli garam tersebut. Berlangsungnya transaksi jual beli di pasar, pembeli tidak mendapatkan informasi mengenai kandungan garam tersebut, pembeli sebatas mendapatkan garam untuk memenuhi kebutuhan sehari-harinya. Setiap kemasan yang dijual tidak disertakan berapa jumlah gram garam yang dijual dengan harga $\mathrm{Rp} 10.000,00$ tersebut.

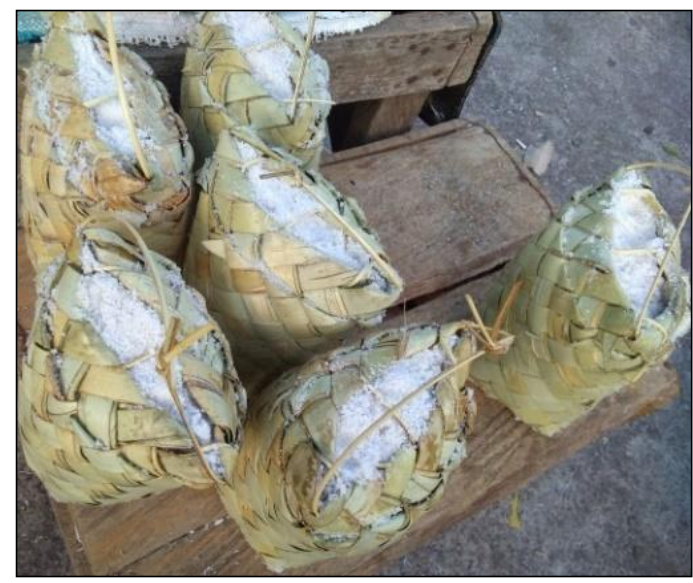

Gambar 3 Pengemasan garam lokal yang di jual di pasar tradisional.

Berbagai permasalahan yang terdapat pada usaha produksi garam rakyat tersebut, tentu memberi dampak bagi para petani garam. Rendahnya kualitas produksi garam serta persaingan dengan garam impor membuat harga garam dalam negeri semakin tertekan yang pada akhirnya berdampak pada kesejahteraan petani garam. Faktor keengganan petani garam untuk berproduksi dan memperbaiki kualitas produksi adalah harga garam di pasar dalam negeri yang tidak stabil dan sering turun drastis (Kompas, 2016). Usaha produksi garam rakyat juga merupakan salah satu roda penggerak perekonomian karena menyediakan lapangan kerja terutama bagi masyarakat di kawasan pesisir Indonesia dan menjadi sarana untuk mengentaskan kemiskinan (Kusumastanto \& Satria, 2014). Peningkatan kualitas garam bertujuan untuk meningkatkan kandungan natrium klorida $(\mathrm{NaCl})$ garam sehingga sesuai dengan peruntukkannya. Secara umum peningkatan kualitas garam dapat dilakukan melalui perbaikan kualitas air laut sebagai bahan baku, perbaikan fasilitas produksi, dan perbaikan setelah garam dihasilkan (Sumada et al., 2016).

Usaha penggaraman dapat menjadi sumber penghasilan masyarakat, khususnya yang berdomisili di pesisir pantai. Namun demikian, besarnya jumlah penghasilan usaha garam sedikitnya ditentukan oleh beberapa faktor utama yaitu luas tambak, masa dan waktu panen, kualitas, dan model pemasaran (Kurniawan et al., 2014). Semakin luas areal tambak yang dimiliki petani, umumnya juga akan memperoleh pendapatan yang lebih besar. Luas lahan garam juga menjadi suatu indikator kemampuan ekonomi dan status sosial petani tambak. Penghasilan petani garam rakyat di Indonesia tidak menentu karena sangat tergantung dari faktor alam. Apabila musim kemarau Panjang maka potensi penghasilan petani semakin tinggi karena frekuensi panen garam semakin banyak, sinar matahari yang cukup merupakan salah satu prasyarat untuk menghasilkan garam yang berkualitas (Aditya P \& Alhayat, 2016).

\section{Kadar NaCl Garam Lokal}

Penentuan karakteristik garam sangat bermanfaat untuk mengetahui besar pengotor yang ada dan kadar $\mathrm{NaCl}$ sebelum dimurnikan sehingga dapat diketahui layak tidaknya garam tersebut untuk di konsumsi. Kadar $\mathrm{NaCl}$ garam lokal di Kabupaten Flores Timur disajikan dalam Tabel 2.

Tabel 2 Kadar $\mathrm{NaCl}$ garam lokal di Kabupaten Flores Timur.

\begin{tabular}{ccc}
\hline $\begin{array}{c}\text { Kode } \\
\text { Sampel }\end{array}$ & $\begin{array}{c}\text { Kadar NaCl } \\
(\boldsymbol{\%})\end{array}$ & SNI 2010 \\
\hline KW & 20,803 & Min 94\% \\
LL & 19,267 & Min 94\% \\
KD & 20,489 & Min 94\% \\
AP & 20,840 & Min 94\% \\
L & 22,439 & Min 94\% \\
M & 21,603 & Min 94\% \\
\hline STDEV & 1,069 & \\
\hline
\end{tabular}

* stedev: Standar Deviasi

Tabel 2 menjelaskan kadar $\mathrm{NaCl}$ setiap lokasi berbeda-beda dan masih jauh untuk sesuai dengan SNI 3556:2010 (94\%). Kualitas garam konsumsi menurut SNI adalah minimal mengandung $\mathrm{NaCl}$ sebesar 94,7\% yang masuk kedalam kisaran kualitas baik (Pusriswilnon, 2006). Rendahnya kadar $\mathrm{NaCl}$ pada garam yang dihasilkan diduga disebabkan pada media tanah dengan banyak zat pengotor, karena bersentuhan langsung dengan tanah, atau dengan kata lain nilai salinitas dan kandungan $\mathrm{NaCl}$ air baku tidak serta merta mempengaruhi nilai $\mathrm{NaCl}$ dan warna dari garam yang dihasilkan (Arwiyah et al., 2015). Pembuatan garam melalui penguapan air laut dengan menggunakan sumber panas matahari, sangat tergantung pada kondisi iklim dan cuaca suatu daerah (Rusiyanto et al., 2013). Kualitas garam yang dikelola secara tradisional pada umumnya harus diolah kembali untuk dijadikan garam konsumsi maupun untuk garam industri (Rositawati et al., 2013). Berdasarkan hasil di atas, dapat diketahui bahwa zat pengotor yang ada dalam garam yang berasal dari air tua dengan kristalisasi biasa masih tinggi dan kadar $\mathrm{NaCl}$ yang terkandung didalamnya masih rendah, sedangkan secara teori garam yang beredar di masyarakat sebagai garam konsumsi harus mempunyai kadar $\mathrm{NaCl}$ minimal 
94,7\% untuk garam yang tidak beriodium (Nitimihardja, 2005).

Zainuri et al. (2016) mengatakan penentu utama rasa asin dari garam adalah konsentrasi $\mathrm{NaCl}$ yang terkandung di dalam butiran garam. Air laut disetiap lokasi mempunyai salinitas yang berbeda mengingat banyak faktor yang mempengaruhinya, diantaranya adalah perbedaan intensitas cahaya matahari, suhu, kelembaban, curah hujan, dan kontribusi air tawar dari darat. Widayat (2009) menyatakan, proses pembuatan garam dengan metode penguapan air laut dengan memanfaatkan energi sinar matahari dipengaruhi oleh beberapa faktor yaitu kecepatan penguapan yang berkaitan dengan banyaknya garam yang diperoleh dan konsentrasi air laut yang berkaitan dengan jumlah garam yang terlarut. Wilayah laut di Flores Timur sebesar 69\%, hal ini menjadikan potensi sumberdaya hayati lautnya sangat besar. Produksi perikanan laut berjumlah 13.766 ton lebih mendominasi dan menjadi salah satu sektor utama pembangunan (BPS Kabupaten Flores Timur, 2014). Produksi perairan umum, tambak, dan kolam tidak tersedianya data produksi sehingga produktivitas perikanan tersebut perlu dikelola dengan baik sehingga pemanfaatan dalam bentuk pengembangan perikanan dapat berlanjut.

Banyak faktor yang diperkirakan berkontribusi terhadap rendahnya produktivitas garam di Indonesia. Pertama, teknik produksi dan peralatan yang digunakan masih sangat tradisional serta produksi garam yang sangat bergantung pada cuaca yang secara umum hanya memungkinkan memproduksi garam hanya dalam waktu 4 bulan (KKP, 2014). Produksi garam di Indonesia sebagian besar juga merupakan produksi garam rakyat dengan luas areal rata-rata sebesar 0,5-3 hektar dengan letak yang terpencarpencar. Kondisi ini menyulitkan pengembangan garam dalam skala besar yang terintegrasi dan efisien yang membutuhkan kesatuan lahan datar yang cukup luas yaitu antara 4.000 hingga 6.000 hektar sehingga mendapat manfaat dari skala ekonomi (Puska PDN, 2012). Faktor lain dari usaha garam hanyalah merupakan mata pencaharian musiman, di mana petani garam seringkali hanya memanfaatkan waktu jeda pada usaha tambak udang sehingga usaha garam rakyat belum dilakukan secara optimal. Dampak iklim terhadap produksi garam bukan hanya berdampak pada penurunan kuantitas produksi garam, tetapi juga mempengaruhi ketersediaan sarana dan prasarana produksi garam yang pada akhirnya dapat turut mempengaruhi kesejahteraan petambak garam (Bramawanto \& Abida, 2017).

Kondisi cuaca yang terkadang tidak menentu dan sulit diprediksi menyebabkan petambak harus meresponnya melalui strategi adaptasi tertentu. Dengan demikian, petambak tetap akan memperoleh penghasilan untuk memenuhi kebutuhan sehari-hari. Saat curah hujan tinggi, petani cenderung lebih memilih untuk menunda atau berhenti produksi (tidak melakukan adaptasi), karena bila proses produksi tetap dilanjutkan maka hasil produksi tidak maksimal bahkan biaya produksi yang telah dikeluarkan tidak mampu ditutupi oleh hasil penjualan saat panen (Aditya P \& Alhayat, 2016).

\section{SIMPULAN}

Kendala yang dihadapi petani garam diantaranya produksi garam masih banyak dilakukan secara tradisional, bergantung pada faktor cuaca, serta kualitas garam yang belum memenuhi standar industri. Lahan penggaraman yang terpisah-pisah menyebabkan skala keekonomian produksi garam tidak tercapai. Terdapat 6 lokasi pengambilan sampel dengan kualitas subjektif berbeda-beda dikarenakan cara produksinya menggunakan cara tradisional. Kualitas garam rakyat yang di produksi disetiap lokasi masih tergolong rendah dari segi kandungan $\mathrm{NaCl}$ untuk sesuai dengan SNI 3556:2010.

\section{SARAN}

Perlu dilakukan pengujian lanjut secara fisik dan kimia untuk meningkatkan kualitas garam yang diproduksi di Kabupaten Flores Timur, sehingga pada saat transaksi jual beli garam di pasar tradisional bisa disertakan informasi kandungan $\mathrm{NaCl}$ pada garam lokal tersebut.

\section{DAFTAR PUSTAKA}

Aditya P \& Alhayat. (2016). Peluang dan Tantangan Komoditas Garam di Indonesia - Info Komoditi Garam. Jakarta: Badan Pengkajian dan Pengembangan Perdagangan Kementerian Perdagangan Republik Indonesia Bekerja sama dengan Al Mawardi Prima Anggota IKAPI DKI Jaya.

Arwiyah, Zainuri M, Efendy M. (2015). Studi Kandungan $\mathrm{NaCl}$ di dalam Air Baku dan Garam yang dihasilkan serta Produktivitas Lahan Garam menggunakan Media Meja Garam yang Berbeda. Jurnal Kelautan, 8, (1), 1-9.

[BPS] Badan Pusat Statistik Kabupaten Flores Timur. (2014). Flores Timur dalam Angka 2014. Larantuka: Badan Pusat Statistik Kabupaten Flores Timur.

Bramawanto R dan Abida RF. (2017). Tinjauan Aspek Klimatologi (ENSO dan IOD) terhadap Produksi Garam Indonesia. Pusat Riset Kelautan, Badan Riset dan Sumber Daya Manusia KP - KKP. Jurnal Kelautan Nasional, 12, (2), 91-99.

Dinas Perikanan dan Kelautan Kabupaten Flores Timur. (2007). Laporan Implementasi Kebijakan Perikanan Berkelanjutan Daerah Flores Timur. Flores Timur: DKP Flores Timur.

Efendy M, Heryanto A, Sidik RF \& Muhsoni FF. (2016). Perencanaan Usaha Korporatisasi Usaha Garam Rakyat. Jakarta: Sekretariat Direktorat Jenderal Pengelolaan Ruang Laut, Kementerian Kelautan dan Perikanan.

Efendy M, Zainuri M \& Hafiluddin. (2014). 
Persembahan Program Studi Ilmu Kelautan untuk Maritim Madura. Intensifikasi Lahan Garam Rakyat di Kabupaten Sumenep. Bangkalan: UTM Press.

[KKP] Kementerian Kelautan dan Perikanan KKP. (2014). Laporan Kinerja Kementerian Kelautan dan Perikanan Tahun 2014. Jakarta: Kementerian Kelautan dan Perikanan (KKP).

[KKP] Kementerian Kelautan dan Perikanan. (2015). Laporan Kinerja Kementerian Kelautan dan Perikanan Tahun 2015. Diunduh tanggal 17 Februari 2019 dari http://kkp.go.id/assets /uploads/2019/03/ LAKIP-KKP-2014.pdf.

[KKP] Kementerian Kelautan dan Perikanan. (2015a). Neraca Garam Nasional Tahun 2011 - 2014. Tidak Dipublikasikan.

Kementerian Perindustrian Republik Indonesia. 2016. Kebutuhan Garam Industri Nasional. Bogor: Kementerian Perindustrian Republik Indonesia.

[BSN] Badan Standarisasi Nasional . (2010). Ketentuan SNI Nomor 3556:2010 Garam Konsumsi Beryodium ICS 71.100.99. Jakarta: Badan Standarisasi Nasional.

Kurniawan, Tikkyrino \& Azizi A. (2012). Climate Change Impact on Salt Ponds Farmers in Sampang and Sumenep Districts. Jurnal Masyarakat dan Budaya, 14, (3), 499-518.

Kurniawan BA, Suryono A \& Saleh C. (2014). Implementasi Program Dana Bantuan Pemberdayaan Usaha Garam Rakyat (PUGAR) dalam Rangka Pengembangan Wirausaha Garam Rakyat (Studi pada Dinas Kelautan dan Perikanan Kabupaten Sumenep). Wacana, 17, (3), 136-148.

Kusumastanto T \& Satria A. (2014). Visi Membangun Desa Pesisir Mandiri 2030. Internet. Diacu pada 28 April 2019 dari https://www.researchgate.net/publication/266 080890_Visi_Membangun_Desa_Pesisir_Ma ndiri_2030\#fullTextFileContent

Nitimihardja AA. (2005). Regulation of The Minister of Industry of The Republic of Indonesia Number 42/M-IND/PER/11/2005 Regarding Preparation, Packaging and Labeling of Iodized Salt, Minister of Industry of the Republic of Indonesia. Internet. Diacu pada 17 Februari 2019 dari www.depperin.go.id/IND/Teknologi/standar/3 .pdf [diakses 17/02/19].

Oktavian R. (2013). Teknologi Produksi Garam pada Lahan Tanah di PT. Garam (persero) Kabupaten Sampang. Laporan PKL. Jurusan Ilmu Kelautan. Universitas Trunojoyo Madura.

[Puska PDN] Pusat Kebijakan Perdagangan Dalam Negeri. (2012). Penerapan Supply Chain
Management untuk Meningkatkan Efisiensi dan Efektifitas Distribusi pada Kasus Garam. Jakarta: Pusat Kebijakan Perdagangan Dalam Negeri, Kementerian Perdagangan.

Pusriswilnon. (2006). Buku Panduan Pengembangan Usaha Terpadu Garam dan Artemia. Pusat Riset Wilayah Laut dan Sumber Daya Non Hayati. Jakarta: Badan Riset Kelautan dan Perikanan Departemen Kelautan dan Perikanan.

Rinto, Arafah E \& Utama SB. (2009). Kajian Keamanan Pangan (Formalin, Garam, dan Mikrobia) pada Ikan Sepat Asin Produksi Indralaya. Jurnal Pembangunan Manusia, 8, (2), 1-11.

Rositawati AL, Taslim CM \& Soetrisnanto D. (2013). Rekristalisasi Garam Rakyat dari Daerah Demak untuk Mencapai SNI Garam Industri. Jurnal Teknologi Kimia dan Industri, 2, (4), 217-225.

Rusiyanto, Soesilowati E \& Jumaeri. (2013). Penguatan Industri Garam Nasional melalui Perbaikan Teknologi Budidaya dan Diversifikasi Produk. Sainteknol, 11, (2), 129-142.

Salim Z \& Munadi E. (2016). Info Komoditi Garam. Jakarta: Badan Pengkajian dan Pengembangan Perdagangan Kementerian Perdagangan Republik Indonesia Bekerja sama dengan Al Mawardi Prima Anggota IKAPI DKI Jaya. 89 - 108.

Setiawan B. 2013. Menganalisis Statistik Bisnis dan Ekonomi dengan SPSS 21. Yogyakarta: CV. Andi Offset.

Sudarmadji S, Haryono B \& Suhardi. (1997). Prosedur Analisa untuk Bahan Makanan dan Pertanian. Yogyakarta: Liberty.

Sulistiyaningsih T, Sugiyono W \& Sedyawati SMR. (2010). Pemurnian Garam Dapur melalui Metode Kristalisasi Air Tua dengan Bahan Pengikat Pengotor $\mathrm{Na}_{2} \mathrm{C}_{2} \mathrm{O}_{4}-\mathrm{NaHCO}_{3}$ dan $\mathrm{Na}_{2} \mathrm{C}_{2} \mathrm{O}_{4}-\mathrm{Na}_{2} \mathrm{CO}_{3}$. Jurnal Kimia, 1, (8), 26-33.

Sumada K, Dewati R \& Suprihatin. (2016). Garam Industri Berbahan Baku Garam Krosok dengan Metode Pencucian dan Evaporasi. Jurnal Teknik Kimia, 11, (1), 30-36.

Widayat W. (2009). Production of Industry Salt with Sedimentation - Microfiltration Process: Optimization of Temperature and Concentration by Using Surface Response Methodology. TEKNIK: Jurnal Ilmiah Bidang Ilmu Kerekayasaan, 30, (1), 11-18.

Zainuri M, Anam K \& Susanti AP. (2016). Hubungan Kandungan Natrium Chlorida $(\mathrm{NaCl})$ dan Magnesium (Mg) dari Garam Rakyat di Pulau Madura. Prosiding Seminar Nasional Kelautan Universitas Trunojoyo Madura 27 Juli 2016 (pp. 167-172). Madura: Universitas Trunojoyo Madura. 